shielding box. The impact of electric waves upon the receiver is indicated by the ringing of the bell. The radiator can be placed at different angular positions. With this apparatus are shown experiments illustrating the opacity of metallic screens, continuous or perforated to electric radiation; the transparency of insulating screens, and the transparency or opacity of various liquids. Water is found to be particularly opaque even in very thin layers. All damp objects are very impervious to this radiation, such as a wet duster, a moist brick, tobacco having more than the legal amount of water added to it, and the human body or hand. The refraction of electric wayes is shown by the use of a paraffin wax prism, the concentration by paraffin lenses, and the polarised quality of the rays by their reflection or stoppage by parallel wire gratings. Also the production of secondary oscillations in linear conductors by hulding rods of metal or tubes of liquid in the radiation. The wave length of the radiation is measured by producing interference as a result of splitting the beam into two portions and transmitting the two portions down two zinc tubes, the relative lengths of which can be adjusted.

Prof. A. C. Haddon, F.R.S., cinematograph photographs of native dances in Torres Straits.

\section{THE RE-ORGANISATION OF THE} EDUCATION DEPARTMENT.

$\mathrm{I}$ introducing the Secondary Education Bill to the House of Lords on Tuesday last, the Duke of Devonshire made the following remarks on the re-organisation of the Education Department :-

"Your lordships may remember that on the Bill of last year some discussion took place upon the future organisation of the Education Department. I thought at the time, and I am still more strongly of opinion now, that that discussion was somewhat premature. It proceeded on the assumption that the organisation of the new office would continue on the same lines as those which had existed when the educational departments were separate and distinct, and that there would be in the new office two divisions, one of which would carry on the work of the old Education Office in connection with elementary education, and the other of which would carry on the work of the Science and Art Department. . . . We now propose to revert to a dual organisation of the office, but not entirely upon the lines of the late Education and Science and Art Departments. The prin. cipal officers of the department which we propose will be a principal permanent secretary, who will supervise generally the whole work of the department. It must be remembered, when special importance is attached to this or that minor subordinate appointment, that it will be the permanent secretary who will be responsible to the President of the Board in the administration of the whole department, and that it is imposible, and would be undesirable if it were possible, that the office should be divided into what I may call water-tight compartments, the head of each of which would be charged with special duties and no other, and that the idea should be entertained that the work of the office should be carried on in several departments, which should have no connection or relation with each other. We propose that under the principal permanent secretary there shall be two principal assistant secretaries, one mainly charged with duties in connection with elementary and the other with secondary education. We propose to abolish the name 'Science and Art Department.' The Science and Art Department will be merged in the secondary education branch of the office. As soon as it may be possible, we propose to transfer the greater part of the staff of the late Science and Art Department from South Kensington to Whitehall, except such part of it as may be necessary to leave at South Kensington for the administration of the museum and the colleges of science and art. In place of the third division that was contemplated, we now propose to give the principal assistant secretary of secondary education two addi. tional assistant secretaries, one of whom will be chiefly charged with the supervision and control of literary instruction, and the other of technological study. This is not the organisation, I admit, to which I partly committed myself last year; but I trust that it may, in substance, meet the views, especially the later views, which have been expressed to me by high educational authorities. With the name we hope to get rid of many of the traditions which were sup. posed to attach to the old Science and Art Department-

NO. I 600 , VOL. 62$]$ traditions which have, I believe, been regarded as opposed to the true interests of education by many of those who have been responsible for the management of the older endowed schools. The original idea of the Science and Art Department was, or at all events was supposed to be, that by means of lectures, classes, and examinations a knowledge of the principles of science and art, which would be valuable to the students themselves and to the nation at large, could be engrafted upon almost any kind of previous elementary or secondary training. It is quite true that this idea has been in recent years very largely modified, but I do not think that it is yet generally known how far the original traditions of the Science and Art Department have been already departed from. We hope and intend that the idea of the future education branch of the office will be to make science and art instruction a part of general education in addition to those classical and literary studies which have hitherto formed its main portion. In the schools and institutions directly assisted by the Board of Education the teaching of science and of art, with the addition, perhaps, of some commercial subjects, will probably remain the principal object. But, on the other hand, in those secondary schools, whether of older or more modern type, which desire to enter into connection with the board, there ought not to be, and there need not be, any interference with the older classical and literary studies so long as there continues to be a demand for them. At the same time, we hope that the scientific resources of the Board will be placed at their disposal if they desire, as many of them do desire, to develop the more modern sides of instruction and education.... It may be of interest to the House to know what are the principal appointments which have been made or are proposed to be made in the principal office of the new secondary education branch of the department. Sir George Kekewich, the late secretary of the Board of Education, has.become the permanent principal secretary of the new Board, and it is he who will be responsible to the President of the Board and to the Government for the administration of the department as a whole. The principal assistant secretary for secondary education will be Sir William Abney, who has done more than any other man in extending the studies of the schools of science under the Science and Art Deptrtment. Under him the assistant secretary to deal with the literary side of instruction will be Mr. Bruce, an assistant commissioner to the Charity Commission under the Endowed Schools Act, who has been chiefly engaged and has obtained much experience in the administration of the Welsh Act. The assistant secretary for technological study has not yet been appointed."

\section{UNIVERSIT Y AND EDUCATIONAL INTELLIGENCE.}

CAMBRIDGE. - Prof. Sir Michael Foster has been nominated by the Council of the Senate as the representative of the University of Cambridge on the Council of the Jenner Institute of Preventive Medicine.

Mr. A. W. Hill, of King's College, and Mr. L. LewtonBrain, of St. John's College, have been appointed University Demonstrators in Botany.

Mr. E. E. Walker, Trinity College, has been elected to the Harkness Scholarship in Geology and Palæontology.

Prof. Woodhead announces ten courses of lectures and demonstrations in Pathology and Bacteriology to be held during the ensuing Long Vacation.

Mr. Shelfurd Bidwell, F.R.S., was on June 19 admitted to the degree of Doctor of Science.

Mr. W. N. Shaw, F.R.S., has been elected a Senior Fellow of Emmanuel College. It is a condition attaching to his tenure that he shall give annually in the University not less than three lectures on the Physics of the Atmosphere or some kindred subject. Mr. C. T. R. Wilson, F.R.S., formerly Clerk Maxwell Student in experimental physics, has been elected to a fellowship at Sidney Sussex College.

The following have been awarded scholarships or exhibitions in Natural Science at the several colleges at the end of the academical year :-

Clare College: Bailey, Cartwright, Cassidy, Hughes.

Pembroke College: Lang, Anderson, Hall.

King's College : Kewley, French, Wilde, Mollison, McIntyre. Christ's College: Fox, Moore, Wilson, Macnab, Muff, Cumberlidge, Sewell 
Emmanuel College: Nixon, Austin, Sutton, Rothera, Banham.

Sidney Sussex College: Bullough, Colt, Drapes, Fearnsides, Harrison, Humphrey, Robinson, Gough.

THE Appointments Gazette, which is the journal of the Cambridge Appointments Association, gives in its last issue (June 1900) much valuable information regarding scientific and other posts open to university graduates. It also contains articles on post graduate work in medicine, by Prof. Allbutt ; on training for business, by Mr. G. E. Foster ; and on Long Vacation courses in French, by Mr. H. J. Millar. A list of some two hundred graduates seeking appointments in various departments of industry, with their university qualifications, ages, \&c., completes the journal. This list might be consulted with advantage by heads of departments and others in search of suitable candidates for vacant appointments. The Association is doing a useful work in bringing together employers and employed in the various walks of life where university training is of importance, and it already possesses a large and influential membership. The Master of Trinity is chairman, Mr. W. N. Shaw, F.R.S., vice-chairman, and Mr. W. A. J. Archbold, secretary.

Prof. Oliver J. Lodge, F.R.S., has been appointed Principal of the University of Birmingham.

THE following appointments at the University College of North Wales, Bangor, are announced:-Mr. W. W. Firth to be assistant lecturer in Electrical Engineering, and $\mathrm{Mr}$. Alexander Darroch to be assistant lecturer in the Day Training Department. Mr. W. Cadwaladr Davies was appointed the representative of the Council upon the Central Welsh B sard, and Mr. H. Bulkeley Price the representative on the Carnarvonshire County Governing Body.

Dr. John Wilizam White, of Philadelphia, has been elected to the John Rhea Barton Chair of Surgery in the University of Pennsylvania; Dr. Frank Morley, of Haverford College, has been appointed professor of mathematics in Johns Hopkins University, vice Prof. Thomas Craig, resigned ; Prof. Charles J. Bartlett takes the place of Prof. M. C. White, who for thirty-three years has filled the chair of pathology in the Medical School of Yale University.

THE Report of the Council to the Governors of the City and Guilds of London Institute, dated March 1900, has just been issued, and gives a full account of the work accomplished in connection with the year I 899 , and contains verbatim reports of the addresses delivered respectively by Sir Andrew Noble and Sir Douglas Fox at the opening of the session, and at the distribution of certificates and prizes. We notice from the report that during the past twenty years the work of the Examinations Department has developed to an enormous extent : thus in 1888 the number of subjects of examination was 24, the number of centres of examination 89 , and the number of candidates 816 . In 1899 the number of subjects had increased to 63 , the number of centres to 397 , and the number of candidates to 14,004; the number of registered classes being 1764 , and of students in attendance 34,176 . These numbers are exclusive of those who receive instruction in manual training. The total number of students last year in the classes registered by the Institute was 36,155 , as compared with 34.990 in the previous year.

THE following gifts and bequests for scientific and educational purposes are noticed in Science:-By the will of the late Jonas G. Clark, of Worcester, Mass, who founded Clark University in 1889 , the entire estate is left to the University, providing the people of Worcester raise a fund of 500,000 dollars. If the sum of 250,000 dollars is raised, he bequeaths 500,000 dollars. If 500,000 dollars is raised, he bequeaths I,000,000 dollars and makes the University his residuary legatee. He also leaves 100,000 dollars for the University library and a similar sum for a department of art. Messrs. Samuel Cupples and Robert S. Brookings have each given to Washington University one-half of the total capital stock of the St. Louis Terminal Cupples Station and Property Company, which company owns the socalled "Cupples Station." The annual income from this gift to the University will be from 120,000 to 130,000 dollars per year. The gift is to form a permanent endowment fund, the interest of which is to be expended by the Board of Directors in any way which it sees fit. Dr. D. K. Pearsons has offered 50,000 dullars to Carleton College, Northfield, Minn., on condition that the college authorities raise 100,000 dollars before January I,
1901. By the will of Henry M. Curry the Western University of Pennsylvania receives 10,000 dollars for scholarships; and the University of Pennsylvania has received 20,000 dollars from Mr. J. D. Lippencott and Mr. J. G. Carruth respectively.

THE second general meeting of the Agricultural Education Committee was held on Friday last at the rooms of the Society of Arts. The report of the executive to the general committee gave a brief account of the constitution and proceedings of the committee from its commencement, and explained that its objects were: (I) to secure systematic and efficient instruction, both theoretical and practical, in agricultural subjects suitable to every class engaged in agriculture; and (2) to diffuse among the agricultural classes a more thorough appreciation of the advantages of instruction bearing directly or indirectly on their industry. The policy of the committee, the report stated, was largely recognised in the new Day School Code; and the block grant, the continuous course of rural instruction, lessons in "common things" given through the standards, and the new subject of household management for girls, were all on the lines of the committee's resolutions. Moreover, the executive believed that it was largely due to the representations of the committee that the new Board of Education, shortly after its formation, issued a circular to managers and teachers of rural elementary schools impressing on them the importance of making education in the village school more consonant with the environment of the scholars than was now usually the case, and especially encouraging the children to gain an intelligent knowledge of the common things which surround them in the country. Other provisions of the new Code were referred to with satisfaction, and the report stated that the committee had not failed to co-operate with the Board of Education in bringing them into effect. With regard to the work which remained to be done, attention should be given to organisation. It would seem that the precedent successfully set some years ago in Scotland of handing over the educational work of the Board of Agriculture to an educational authority, while leaving to the Board the inspection of experimental and research work, might well be followed. If that was not done, and the present division of functions continued, the cause of rural education, especially in its higher branches, would undoubtedly suffer. It was also to be hoped that attention would be given to the training of teachers, and that the new Board would introduce some modifications into the curricula of the training colleges to ensure the qualification of a certain number of trained teachers to give instruction on elementary science and common things required by the Code. A good deal also remained to be done in placing evening continuation work on a satisftctory footing.

\section{SCIENTIFIC SERIALS.}

American Journal of Science, June.-A method of studying the diffusion (transpiration) of air through water, and a method of barometry, by C. Barus. The diffusion of air through water is studied by observing the gradual loss of the air contained in a Cartesian diver, and this loss is determined from the change in the temperature coefficient contained in the equation of flotation. The same equation also involves in a simple manner the height of the barometer; and a Cartesian diver apparatus is, therefore, virtually a water barometer which need only be one foot high instead of thirty feet. - Separation and determination of mercury as mercurous oxalate, by C. $A$. Peters. The anthor estimates mercurous salts volumetrically by precipitating with ammonium oxalate, and determining the oxalic acid by potassium permanganate, and gravimetrically by direct weighing of the precipitate.-Electrical resistance of thin films deposited by kathode discharge, by A. C. Longden. The thinnest films have a resistance which is very much higher than is warranted by their thinness. The sign of the temperature coefficient of resistance varies with the thickness, and it is therefore possible to obtain resistances by kathode-ray deposition which do not vary with the temperature. Such resistances form valuable high-resistance standards. $\rightarrow$ New meteorite from Oakley, Logan county, Kansas, by H. L. Preston. This is a siderite of $6 \mathrm{I}$ lbs. found in $\mathrm{I} 895$. Some observations on certain well-marked stages in the evolution of the Testudinate humerus, by G. R. Wieland. The development of the humerus of the turtle presents a special interest on account of its graduated change of habitat from dry deserts to the ocean. -Geothermal gradient in Michigan, by A. C. Lane. The geothermal gradient at Bay City is $I_{5} 5$ degrees $F$. per 100

NO. I600, VOL. 62 ] 